\title{
Readiness of adolescents to use genetically modified organisms according to their knowledge and emotional attitude towards GMOs
}

\author{
Stanisław Lachowski ${ }^{1}$, Anna Jurkiewicz ${ }^{2}$, Piotr Choina ${ }^{2}$, Magdalena Florek-Łuszczki², \\ Agnieszka Buczaj ${ }^{3}$, Małgorzata Goździewska² \\ ${ }^{1}$ Maria Curie-Skłodowska University, Lublin, Poland \\ ${ }^{2}$ Institute of Rural Health in Lublin, Poland \\ ${ }^{3}$ University of Life Sciences in Lublin, Poland
}

Lachowski S, Jurkiewicz A, Choina P, Florek-Łuszczki M, Buczaj A, Goździewska M Readiness of adolescents to use genetically modified organisms according to their knowledge and emotional attitude towards GMOs. Ann Agric Environ Med. 2017; 24(2): 194-200. https://doi.org/10.26444/aaem/74478

\begin{abstract}
Introduction. Agriculture based on genetically modified organisms plays an increasingly important role in feeding the world population, which is evidenced by a considerable growth in the size of land under genetically modified crops (GM). Uncertainty and controversy around GM products are mainly due to the lack of accurate and reliable information, and lack of knowledge concerning the essence of genetic modifications, and the effect of GM food on the human organism, and consequently, a negative emotional attitude towards what is unknown.

Objective. The objective of the presented study was to discover to what extent knowledge and the emotional attitude of adolescents towards genetically modified organisms is related with acceptance of growing genetically modified plants or breeding GM animals on own farm or allotment garden, and the purchase and consumption of GM food, as well as the use of GMOs in medicine.

Materials and method. The study was conducted by the method of a diagnostic survey using a questionnaire designed by the author, which covered a group of 500 adolescents completing secondary school on the level of maturity examination. The collected material was subjected to statistical analysis. Research hypotheses were verified using chi-square test $\left(\mathrm{X}^{2}\right)$, t-Student test, and stepwise regression analysis.

Results. Stepwise regression analysis showed that the readiness of adolescents to use genetically modified organisms as food or for the production of pharmaceuticals, the production of GM plants or animals on own farm, depends on an emotionalevaluative attitude towards GMOs, and the level of knowledge concerning the essence of genetic modifications.
\end{abstract}

I Key words

adolescents, GMO, knowledge, emotions, use of GMOs

\section{INTRODUCTION}

The development of molecular biology and the possibilities created by genetic engineering are great achievements which have been observed since the second half of the $20^{\text {th }}$ century [1].

Genetic engineering, which is the basis of modern technology, is of crucial importance for the development of the bio-economy. At present, achievements in bio-technology are applied in plant cultivation, animal breeding, protection of nature, medicine, and in industry, e.g. pharmaceutical. However, the best known use of genetic engineering are modifications of functional plants and animals in order to improve their properties in a way that better fulfils their role in feeding humans [2]. Transgenic food, opposite to traditional food, may possess new features, among others, changed nutritional value, as well as health, technological and sensor properties [3].

Agriculture based on genetically modified organisms plays an increasingly important role in feeding the world's population, which is evidenced by a considerable growth in the size of land under GM crops. According to the

Address for correspondence: Anna Jurkiewicz, Institute of Rural Health E-mail: annajurkiewicz@op.pl

Received: 27 December 2013; accepted: 08 July 2014; first published on February 2017
International Service for the Acquisition of Agri-biotech Applications (ISAAA), from 1996 - $2012 \mathrm{~m}$ the area of GM crops increased by as much as 100 times, from $1.7 \mathrm{mln}$ ha $170 \mathrm{mln}$ ha $[4,5,6]$.

Increasingly more often we consume food products without realizing that they contain genetically modified organisms in their composition, e.g. soya, sweet corn, rapeseed oil, fruit, vegetables, fish and poultry.

Studies conducted in European supermarkets showed that on the shop shelves there are few products labelled with information concerning the contents of GMO $[7,8]$. The principles of labelling genetically modified products are specified in Regulation (EC) No. 1830/2003 of the European Parliament and of the European Council of 22 September 2003, according to which products containing GMO must be labelled, and ensure accurate information on the package if the content of GMO is not lower than $0.9 \%$ of their mass. In the case when the entire product is genetically modified, it should be labelled as a 'genetically modified product'. If only some of its ingredients are genetically modified, beside the name of the ingredient, it should be labelled with the words 'genetically modified'. The label and the information should be legibly written with a font size the same as the name of the ingredient or product. The lack of adequate labelling of a GMO product is an offence punishable by a fine [9]. 
The dynamic development of bio-technology observed in recent years evokes serious social concerns about potential risk due to uncontrolled penetration of dangerous transgenes into the natural environment or consumers' organisms. Thus, these concerns pertain to the health consequences of the consumption of GM food which, from a manygeneration perspective, are not known and difficult to foresee. Evaluations of organisms produced using genetic engineering are most often affected by targeted opinionforming actions, campaigns concerning GMO, common, or even purely ethical-moral opinions, and legal patents for life $[10,11,12,13]$.

Uncertainty and controversy around GM products are mainly due to the lack of accurate and reliable information, and lack of knowledge concerning the essence of genetic modifications, and the effect of GM food on the human organism, and consequently, a negative emotional attitude towards what is unknown $[14,15,16]$.

\section{OBJECTIVE}

The objective of the presented study was to discover to what extent knowledge and the emotional attitude of adolescents towards genetically modified organisms is related with acceptance of growing genetically modified plants or breeding GM animals on own farm or allotment garden, and the purchase and consumption of GM food, as well as the use of GMOs in medicine.

\section{MATERIALS AND METHOD}

The study covered a group of 500 adolescents (250 students - General Secondary School; 250 students - Secondary Technical Agricultural School) from the Lublin Region of eastern Poland, completing secondary school on the level of maturity examination during the school year 2010/2011. $58.4 \%$ of respondents were girls, and $41.6 \%$ boys. The majority of adolescents in the study lived in rural areas $-73.4 \%$, only $26.6 \%$ were urban inhabitants. More than a half of respondents $(51.8 \%)$ came from agricultural families, while the remainder (48.2\%) from non-agricultural families (Tab. 1).

Table 1. Characteristics of adolescents in the study completing secondary schools

\begin{tabular}{llcc}
\hline Characteristics & & $\mathrm{N}$ & $\%$ \\
\hline \multirow{3}{*}{ Gender } & Girls & 292 & 58.4 \\
\cline { 2 - 4 } & Boys & 208 & 41.6 \\
\cline { 2 - 4 } & Total & 500 & 100 \\
\hline \multirow{3}{*}{ Place of residence } & Urban area & 133 & 26.6 \\
\cline { 2 - 4 } & Rural area & 367 & 73.4 \\
\cline { 2 - 4 } & Total & 500 & 100 \\
\hline \multirow{3}{*}{ Origin* } & Agricultural & 253 & 51.8 \\
\cline { 2 - 4 } & Non-agricultural & 235 & 48.2 \\
\cline { 2 - 4 } & Total & 488 & 100 \\
\hline \multirow{2}{*}{ Type of school } & General Secondary School & 250 & 50 \\
\cline { 2 - 4 } & Secondary Technical Agricultural School & 250 & 50 \\
\cline { 2 - 4 } & Total & 500 & 100 \\
\hline
\end{tabular}

* - lack of data was not considered; $\mathrm{N}$ - number of respondents
The study was conducted by the method of a diagnostic survey, using a questionnaire. The questionnaire contained 82 items concerning the following problems:

1) respondents' knowledge concerning genetic modification and genetically modified organisms;

2) emotional attitude towards GMO;

3) health assessment of GMOs and food produced based on GM organisms;

4) readiness to grow and breed genetically modified organisms;

5) socio-demographic data concerning the adolescents in the study.

The research material collected was subjected to statistical analysis. Research hypotheses were verified using statistical tests: chi-square $\left(\chi^{2}\right)$, t-Student, and stepwise regression analysis. Multiple stepwise regression required the conversion of qualitative data into quantitative data (Likert scale). For this purpose, qualitative criteria describing the respondents' emotional attitude towards GMOs (emotional component of attitude), and readiness to use genetically modified organisms (behavioural component) were ascribed numerical values according to a scale from 1-4, where 1 - meant definite rejection of a given statement, and 4 - its definite acceptance. Mean values for individual characteristics were calculated for the total population sample and for subgroups of girls and boys. In order to specify the strength of the relationship between the indicators of respondents' knowledge, and their emotional attitude towards GMOs and behavioural indicators, stepwise regression analysis was performed.

\section{RESULTS}

Knowledge of adolescents completing secondary schools concerning genetic modification of organisms. Analysis of the research material showed that the majority of adolescents completing secondary schools $(70.9 \%)$ were not interested in the scope of problems concerning genetic modification of organisms (GMOs), and only less than $1 / 3$ of them (29.0\%) showed an interest in this problem - boys significantly more often than girls $(32.2 \%$ and $26.8 \%$, respectively (Tab. 2$)$. It should be presumed that the low interest in the scope of problems concerning GMOs resulted from low self-reported knowledge of the problem. More than 3/4 of adolescents in the study (78.3\%) admitted that they had no knowledge concerning GMOs, or that their knowledge was rather poor, while every fifth respondent evaluated his/her level of knowledge as rather high, while only $1.6 \%$ - as very high (Tab. 2). A high level of knowledge concerning GMO was declared by a similar percentage of girls and boys, whereas high differences were observed between boys and girls who evaluated their knowledge as poor. Boys nearly twice as frequently as girls admitted that they had no knowledge concerning GMOs. The adolescents in the study similarly evaluated their scope of information pertaining to health effects resulting from the consumption of products prepared based on GMOs.

In order to investigate the validity of evaluations concerning self-reported knowledge of GMOs and its actual level, the adolescents were asked 4 detailed questions concerning this problem. Considering the correctness of the replies provided to these questions, the respondents' knowledge was assessed according to a 5-degree scale: 
1) lack of knowledge (no correct answers);

2) low level of knowledge (1 correct reply);

3) mediocre level of knowledge (2 correct replies);

4) rather high level (3 correct);

5) very high level of knowledge (all replies correct).

While adopting the above-presented criteria it was found that the highest percentage of adolescents in the study (38.4\%) possessed a mediocre level of knowledge concerning GMOs, a slightly lower percentage $(31.3 \%)$ had a low level of knowledge, and $12 \%$ of respondents failed to give any correct answers. Nearly 1/5 of respondents showed a high knowledge concerning problems related with GMOs. The level of knowledge of the problem was similar among girls and boys (Tab. 2).

Table 2. Indicators of adolescents' knowledge concerning GMO according to gender

\begin{tabular}{|c|c|c|c|c|c|c|}
\hline & \multicolumn{4}{|c|}{ Gender } & \multirow{2}{*}{\multicolumn{2}{|c|}{ Total }} \\
\hline & \multicolumn{2}{|c|}{ Girls } & \multicolumn{2}{|c|}{ Boys } & & \\
\hline & $\mathrm{N}$ & $\%$ & $\mathrm{~N}$ & $\%$ & $\mathrm{~N}$ & $\%$ \\
\hline \multicolumn{7}{|c|}{ Interest in the scope of problems concerning GMO } \\
\hline Definitely No & 45 & 15.5 & 38 & 18.3 & 83 & 16.6 \\
\hline Rather No & 168 & 57.7 & 103 & 49.5 & 271 & 54.3 \\
\hline Rather Yes & 71 & 24.4 & 50 & 24 & 121 & 24.2 \\
\hline Definitely Yes & 7 & 2.4 & 17 & 8.2 & 24 & 4.8 \\
\hline Total & $291^{*}$ & 100 & 208 & 100 & 499 & 100 \\
\hline \multicolumn{7}{|c|}{ Self-reported knowledge concerning GMO } \\
\hline I know nothing & 42 & 14.4 & 56 & 26.9 & 98 & 19.6 \\
\hline I know rather a little & 186 & 63.9 & 107 & 51.4 & 293 & 58.7 \\
\hline I know rather a lot & 59 & 20.3 & 41 & 19.7 & 100 & 20 \\
\hline I know a lot & 4 & 1.4 & 4 & 1.9 & 8 & 1.6 \\
\hline Total & $291^{*}$ & 100 & 208 & 100 & 499 & 100 \\
\hline \multicolumn{7}{|c|}{ Evaluation of knowledge concerning health effects of GMO } \\
\hline I know very little & 81 & 27.7 & 70 & 33.7 & 151 & 30.2 \\
\hline I know rather a little & 154 & 52.7 & 102 & 49 & 256 & 51.2 \\
\hline I know rather a lot & 50 & 17.1 & 34 & 16.3 & 84 & 16.8 \\
\hline I know a lot & 7 & 2.4 & 2 & 1 & 9 & 1.8 \\
\hline Total & 292 & 100 & 208 & 100 & 500 & 100 \\
\hline \multicolumn{7}{|c|}{ Level of knowledge concerning GMO } \\
\hline Lack of knowledge & 26 & 9.9 & 28 & 14.8 & 54 & 12 \\
\hline Low & 79 & 30.2 & 63 & 33.3 & 142 & 31.5 \\
\hline Mediocre & 109 & 41.6 & 64 & 33.9 & 173 & 38.4 \\
\hline Rather high & 47 & 17.9 & 30 & 15.9 & 77 & 17.1 \\
\hline High & 1 & 0.4 & 4 & 2.1 & 5 & 1.1 \\
\hline Total & $262^{*}$ & 100 & $189^{*}$ & 100 & 451 & 100 \\
\hline
\end{tabular}

* - lack of data was not considered; $\mathrm{N}$ - number of respondents

Evaluation of genetic modification of organisms and genetically modified food. Opinions about the importance of GMOs are divided, among researchers as well as among food producers and consumers. Many arguments are produced for and against actions on behalf of the development of breeding GM animals and the cultivation of GM crops. There is no unequivocal evaluation of the consequences of using these organisms in food production or as feed for animals. While introducing the adolescents into the study they were presented with various opinions concerning GMOs in order to discover their opinions in this respect.

Analyses showed that secondary school adolescents perceived both positive and negative consequences of breeding GM animals (Fig. 1). Opinions concerning positive effects of animal breeding, such as: possibility to produce new drugs, higher cost-effectiveness of breeding, higher resistance to diseases, or possibility to produce organs for transplants, obtained acceptance over the mean value (acceptance indicators from $2.9-2.8$, theoretical mean 2.5). A similar level of acceptance was obtained with respect to the negative opinions: occurrence of new diseases (3.0), extinction of traditional species (2.9), uncontrolled occurrence of new species and breeds (2.8), and loss of control over GM species purity (2.7) (Fig. 1).

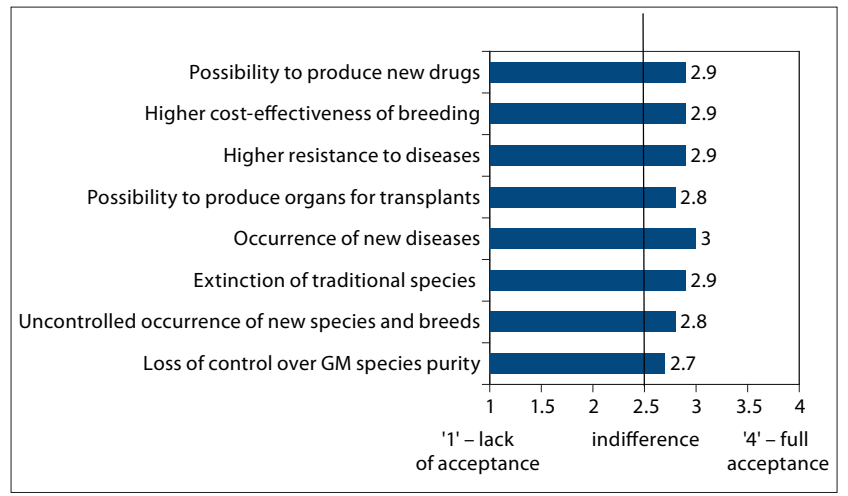

Figure 1. Level of acceptance of positive and negative opinions concerning consequences of breeding of GM animals among adolescents in the study

The respondents' opinions concerning various consequences of the cultivation of genetically modified plants are more varied, compared to their opinions pertaining to animal breeding (Fig. 2). The most accepted arguments are that the cultivation of GM plants increases crops, costeffectiveness of cultivation, increases the resistance of plants to diseases, and decreases the use of mineral fertilizers. Less accepted was the opinion that the cultivation of GM plants results in a lower pollution of the natural environment. In the case of the negative consequences of cultivation of GM plants, the highest level of acceptance was observed concerning the fact that these crops supercede traditional crops (mean level of acceptance 2.9), whereas the lowest level - concerning the opinion that there is a risk of loss of control over the spread of GM plants (mean level of acceptance 2.6) (Fig. 2).

Analysis of data in Table 3 indicates that the mean level of acceptance by the adolescents examined of positive and

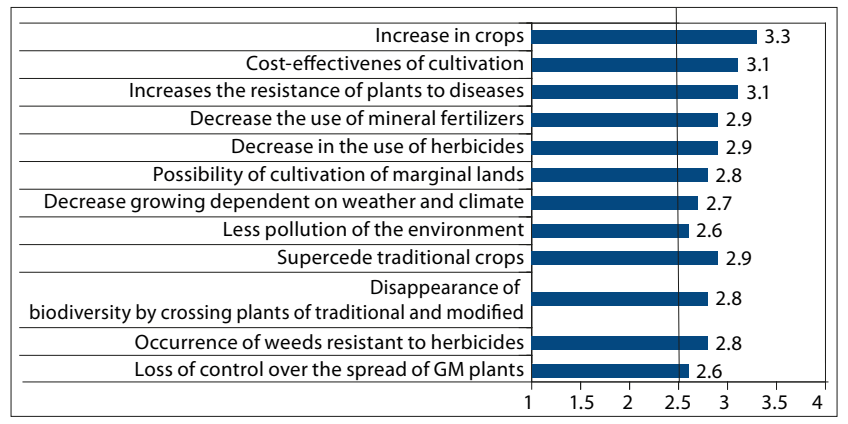

Figure 2. Level of acceptance of positive and negative consequences of cultivation of GM plants among adolescents in the study 
negative opinions concerning the of genetically modified animals was similar (positive 2.90; negative 2.88). In the case of cultivation of GM plants, the mean level of acceptance of positive and negative opinions significantly differed statistically. Positive opinions were more accepted (2.94) than the negative opinions (2.81) $(\mathrm{t}=4.469, \mathrm{p}<0.001)(\mathrm{Tab} .3)$.

Table 3. Comparison of mean indicators of level of acceptance of positive and negative consequences of cultivation of GM plant and breeding GM animals

\begin{tabular}{|c|c|c|c|c|c|c|c|}
\hline $\begin{array}{l}\text { Indicators } \\
\text { of level of } \\
\text { acceptance }\end{array}$ & $\begin{array}{l}\text { Type of } \\
\text { conse- } \\
\text { quences }\end{array}$ & Mean & $\begin{array}{l}\text { Standard } \\
\text { deviation }\end{array}$ & $\begin{array}{c}\text { Difference } \\
\text { in mean } \\
\text { values }\end{array}$ & $\begin{array}{l}\text { Standard } \\
\text { deviation }\end{array}$ & $\mathrm{t}$ & $p$ \\
\hline \multirow{2}{*}{$\begin{array}{l}\text { Cultivation of } \\
\text { plants }\end{array}$} & Positive & 2.94 & 0.55 & \multirow{2}{*}{0.13} & \multirow{2}{*}{0.65} & \multirow{2}{*}{-4.47} & \multirow{2}{*}{0.00} \\
\hline & Negative & 2.81 & 0.59 & & & & \\
\hline \multirow{2}{*}{$\begin{array}{l}\text { Breeding of } \\
\text { animals }\end{array}$} & Positive & 2.90 & 0.62 & \multirow{2}{*}{0.02} & \multirow{2}{*}{0.74} & \multirow{2}{*}{0.62} & \multirow{2}{*}{0.54} \\
\hline & Negative & 2.88 & 0.58 & & & & \\
\hline
\end{tabular}

Among the indicators of the emotional component of respondents' attitudes towards GMOs was evaluation of the importance of genetically modified organisms on the health qualities of food produced based on GM organisms, scientific importance of achievements of genetic engineering, effects of usage of GM organisms for food production, and the importance of GM in animal breeding and plant cultivation. The adolescents in the study evaluated according to the scale from 1 - 4 ( 1 - negative evaluation; 4 - positive evaluation) individual ways of using GMOs. Considering the opinions expressed by the respondents, it was found that all ways of using GM organisms obtained evaluations below the theoretical mean (2.5), and reached the value of 2.27 (Fig. 3). This means that adolescents completing secondary schools tended to express slightly more negative evaluations concerning GMOs. At the same time, it should be noted that the evaluations of the importance of individual aspects of usage of GM organisms were similar. Slightly higher values were found with respect to the improvement of health qualities of food produced based on GM organisms (2.36), and the importance of achievements of genetic engineering for science (2.36) (Fig. 3).

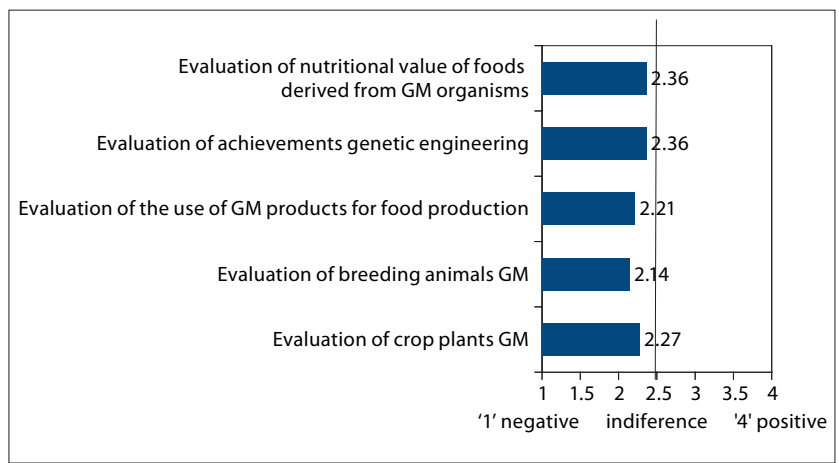

Figure 3. Evaluation of various ways of using genetically modified organisms

Factors conditioning readiness to use GM organisms. The behavioural component of the attitude towards GMO was analyzed from 3 aspects:

1) readiness to buy food produced based on GM organisms;

2) readiness to carry out agricultural production with the use of GM organisms;

3) readiness to undergo treatment using GM organisms.
Readiness for individual behaviours was evaluated according to a 4-degree scale, where ' 1 ' - lack of readiness, and ' 4 ' - complete readiness. The calculated values of readiness for using GMOs allows the presumption that the adolescents in the study showed the greatest readiness to purchase food produced based on GM organisms (Tab. 4). The value of this indicator was the highest (2.62), although only slightly higher than the theoretical mean (2.5). To a considerably lesser extent, the respondents were ready to undergo treatment using GM organisms (2.17), followed by carrying out agricultural production with the use of GM organisms (2.10) (Tab. 4).

Table 4. Mean indicators of readiness to use GM organisms according to respondents' gender

\begin{tabular}{|c|c|c|c|c|c|c|c|}
\hline Indicators & Gender & Mean & $\begin{array}{c}\text { St. } \\
\text { dev. }\end{array}$ & $\begin{array}{l}\text { Difference } \\
\text { in mean } \\
\text { values }\end{array}$ & $\begin{array}{l}\text { St. } \\
\text { error }\end{array}$ & $\mathrm{t}$ & $p$ \\
\hline \multirow{3}{*}{$\begin{array}{l}\text { Readiness to } \\
\text { purchase food based } \\
\text { on GM organisms }\end{array}$} & Girls & 2.68 & 0.64 & \multirow{2}{*}{0.13} & \multirow{2}{*}{0.63} & \multirow{2}{*}{2.09} & \multirow{2}{*}{0.04} \\
\hline & Boys & 2.55 & 0.72 & & & & \\
\hline & Total & 2.62 & 0.67 & & & & \\
\hline \multirow{3}{*}{$\begin{array}{l}\text { Readiness to carry } \\
\text { out agricultural } \\
\text { production using GM } \\
\text { organisms }\end{array}$} & Girls & 1.96 & 0.62 & \multirow{2}{*}{-0.34} & \multirow{2}{*}{0.64} & \multirow{2}{*}{5.14} & \multirow{2}{*}{0.000} \\
\hline & Boys & 2.30 & 0.80 & & & & \\
\hline & Total & 2.10 & 0.71 & & & & \\
\hline \multirow{3}{*}{$\begin{array}{l}\text { Readiness to } \\
\text { undertake treatment } \\
\text { using GM organisms }\end{array}$} & Girls & 2.10 & 0.86 & \multirow{2}{*}{-0.23} & \multirow{2}{*}{0.83} & \multirow{2}{*}{-3.32} & \multirow{2}{*}{0.000} \\
\hline & Boys & 2.33 & 0.98 & & & & \\
\hline & Total & 2.17 & 0.92 & & & & \\
\hline
\end{tabular}

While searching for factors conditioning readiness to use GM organisms, stepwise regression analysis was applied. The hypothesis was adopted that behaviours towards GMOs (behavioural component of attitude) are significantly related with an emotional-judging attitude and knowledge concerning these organisms. In addition, socio-demographic variables were introduced into the model of conditionings,, such as respondents' gender, place of residence, and type of school attended (Tab. 1).

The conducted analysis showed that readiness to buy food produced based on GMOs is explained by factors specifying emotional-judgement attitude towards GMOs, such as: evaluation of GM products $(\beta=0.310)$, level of acceptance of opinions concerning positive effects of cultivation of GM plants $(\beta=0.126)$, and degree of trust in products manufactured based on GM organisms $(\beta=0.117)$. The values of the coefficients $\beta$ showed that the more positive the adolescents' emotional attitude towards GMOs, the higher their readiness to buy food containing GM organisms (Tab. 5). In addition, girls were more apt to purchase this type of food, compared to boys ( $\beta=-0.148$ ). The above-mentioned factors explain jointly $22 \%$ of variance of the variable 'readiness to buy food containing GMOs'.

An identical model of conditioning was observed with respect to readiness to undergo treatment using GMOs (Tab. 5). In this case, the indicators $\beta$ are higher. This model explains approximately $33 \%$ of variance of the variable 'readiness to use GMOs in treatment'.

Slightly different predictors explain the readiness of the adolescents in the study to carry out agricultural production using GMOs. This form of behaviour was related with both an emotional-judgement attitude towards GMOs, and knowledge concerning GM organisms. The more positive 
Table 5. Readiness to buy products based on GM organisms and indicators of knowledge and emotional attitude towards these products (results of stepwise regression analysis)

\begin{tabular}{|c|c|c|c|c|c|c|}
\hline \multirow[t]{2}{*}{ Predictors } & \multicolumn{2}{|c|}{$\begin{array}{l}\text { Non- } \\
\text { standardized } \\
\text { coefficients }\end{array}$} & \multirow{2}{*}{$\begin{array}{l}\text { Standard- } \\
\text { ized } \\
\text { coeffi- } \\
\text { cients } \beta\end{array}$} & \multirow[t]{2}{*}{$\mathrm{t}$} & \multirow[t]{2}{*}{$p$} & \multirow[t]{2}{*}{$\begin{array}{l}\text { Cor- } \\
\text { rectec } \\
\mathrm{R}^{2}\end{array}$} \\
\hline & $\beta$ & St. dev. & & & & \\
\hline \multicolumn{7}{|c|}{ Readiness to buy products based on genetically modified organisms } \\
\hline (intercept) & 1.521 & 0.174 & & 8.766 & 0.000 & \\
\hline $\begin{array}{l}\text { Indicator of evaluation of } \\
\text { GM products }\end{array}$ & 0.428 & 0.047 & 0.310 & 5.119 & 0.000 & \\
\hline Gender $^{1}$ & -0.202 & 0.058 & -0.148 & -3.477 & 0.001 & \\
\hline $\begin{array}{l}\text { Level of acceptance of } \\
\text { opinions concerning } \\
\text { positive consequences of } \\
\text { GM crops }\end{array}$ & 0.155 & 0.057 & 0.126 & 2.727 & 0.007 & 0.220 \\
\hline $\begin{array}{l}\text { Level of trust in products } \\
\text { based on GM organisms }\end{array}$ & 0.098 & 0.048 & 0.117 & 2.048 & $<0.05$ & \\
\hline
\end{tabular}

Readiness to carry out agricultural production using genetically modified organisms

\begin{tabular}{|c|c|c|c|c|c|c|}
\hline (intercept) & -0.164 & 0.135 & & -1.211 & 0.227 & \\
\hline $\begin{array}{l}\text { Indicator of evaluation of } \\
\text { GM products }\end{array}$ & 0.602 & 0.051 & 0.548 & 11.906 & 0.000 & \\
\hline Gender $^{1}$ & 0.235 & 0.052 & 0.162 & 4.493 & 0.000 & \\
\hline $\begin{array}{l}\text { Level of trust in products } \\
\text { based on GM organisms }\end{array}$ & 0.156 & 0.041 & 0.176 & 3.769 & 0.000 & 0.505 \\
\hline Type of school ${ }^{2}$ & 0.110 & 0.052 & 0.077 & 2.129 & 0.034 & \\
\hline $\begin{array}{l}\text { Level of knowledge } \\
\text { concerning GMO }\end{array}$ & 0.055 & 0.026 & 0.072 & 2.064 & 0.040 & \\
\hline
\end{tabular}

Readiness to undertake treatment using genetically modified organisms

\begin{tabular}{|c|c|c|c|c|c|c|}
\hline (intercept) & -0.411 & 0.221 & & -1.860 & 0.064 & \\
\hline $\begin{array}{l}\text { Indicator of evaluation of } \\
\text { GM products }\end{array}$ & 0.452 & 0.077 & 0.318 & 5.837 & 0.000 & \\
\hline $\begin{array}{l}\text { Level of acceptance of } \\
\text { opinions concerning } \\
\text { positive consequences of } \\
\text { GM crops }\end{array}$ & 0.285 & 0.063 & 0.190 & 4.516 & 0.000 & 0.326 \\
\hline $\begin{array}{l}\text { Level of trust in products } \\
\text { based on GM organisms }\end{array}$ & 0.220 & 0.062 & 0.192 & 3.574 & 0.000 & \\
\hline Gender & 0.201 & 0.076 & 0.107 & 2.651 & 0.008 & \\
\hline
\end{tabular}

'codes for 'gender': ' 1 ' - girls; '2' - boys.

'codes for 'type of school': ' 1 ' - General Secondary School; '2' - Secondary Technical Agricultural School.

the attitude towards GMOs, the higher the level of knowledge concerning these organisms, and the greater the readiness of adolescents to carry out agricultural production with their use. In addition, the type of school attended by adolescents and the respondents' gender were significantly related with this aspect of their attitude. Adolescents attending Secondary Technical Agricultural Schools were more willing to undertake cultivation of GM crops or breeding of GM animals, compared to adolescents from general Secondary Schools, also boys more than girls. These factors jointly explain approximately $51 \%$ of variance of the variable 'readiness to carry out agricultural production with the use of GMOs'.

\section{DISCUSSION}

All human behaviours are, on the one hand, determined by emotional needs, and on the other, by experience and knowledge - knowledge of regulations and principles governing individual and social life. Interiorization of these markers and shaping of attitudes allows the making of internally coherent decisions, and undertaking actions in accordance with the whole of personality-temperament traits, thus socially accepted [17].

The age of adolescence is the period of special intensification of seeking one's own road in life and the shaping of attitudes. Knowledge about the world, humans and nature acquired at school, and own outside school experiences - family, friends - become structuralized in the form of defined emotionalpersonality traits which, in turn, delineate behaviours. The activity of adolescents increasingly more often concerns also consumer behaviours, including attitudes towards mode of nutrition.

In recent years, agriculture based on GMOs has played an increasingly greater role in feeding the population of the world, which is evidenced by a considerable increase in the size of land under GM plants $[18,19,20]$. Food products based on GMOs are systematically more widely available. Increasingly more frequently we consume foods without realizing that they may contain GM organisms in their composition. While trying to predict the directions in the development of bio-technology, the social reception of its achievements should also be considered.

The results of the presented study conducted among adolescents completing secondary schools are in accordance with the attitude of Polish society and societies of many countries concerning GM crops cultivation and breeding of GM animals. These attitudes are characterized by a great distrust with respect to transgenic food, and the feeling of threat for the existence of humanity on the part of modern achievements of natural sciences, including bio-technology $[21,22]$. This is partly an effect of the lack of genuine knowledge concerning the essence of genetic engineering, the source of which are mainly opinions from acquaintances of from non-professionals. These opinions most frequently express distrust towards anything new, according to the principle 'never enough caution' [23].

Studies of the social opinions conducted in Poland, as well as in other countries of the EU, show that the consumers possess poor knowledge concerning bio-technology, genetic engineering or genetically modified organisms [21]. The lack of knowledge declared by them is often related with the lack of acceptance for bio-technology and, more rarely, with a neutral attitude. In turn, a superficial knowledge of the problem evokes concerns and resistance towards genetic engineering, and negation of its achievements - 'emotions over the brain'. Reliable, comprehensive knowledge allows the perception of both the positive and negative aspects of the achievements of bio-technology, referring to the rational arguments of the view assumed [24]. Therefore, an important marker of consumer behaviour with respect to GM products is the level of their knowledge concerning the essence of genetic changes introduced in bio-technological laboratories.

The presented study shows that nearly $3 / 4$ of adolescents completing secondary schools are not interested in the scope of problems concerning GMOs. This results from their poor knowledge of the problem. Considering the correctness of the 
replies provided to the questions concerning the essence of genetic modifications, the highest percentage of respondents possessed a mediocre level of knowledge, a slightly lower percentage had a poor knowledge, and every tenth respondents had no information concerning this problem. Despite the low level of knowledge of problems pertaining to the essence of GMOs, all respondents were capable of expressing their emotional attitude towards agricultural production with the use of GMOs.

With respect to breeding GM animals, the adolescents in the study perceived both the negative consequences and positive effects. In general, however, they were either definite supporters or definite contrarians of breeding GM animals.

In turn, their opinions concerning various consequences of cultivation GM plants varied, and depended on the type of effects predicted for humans and the natural environment. This may be due to the fact that the world of plants seems to be more prone to natural species changes, compared to the animal world. It would be enough to be a cautious client of food supermarkets to notice many varied new species of fruits and vegetables, frequently produced by a change in their genotype. Due to their organoleptic and visual qualities, we willingly reach for them and consume them, not even knowing their names [23].

The adolescents in the study also relatively often declared willingness to buy products containing GMOs. The calculations performed using stepwise regression analysis indicated that girls were more apt to buy GM food than boys, also the readiness for purchasing food produced based on GMOs to a greater extent depended on an emotionaljudgment attitude than on the intellectual components of attitude towards GMOs. Girls, who attached more importance to nutrition than boys, more emotionally responded to any advertisements for food products, including those containing GMOs.

Considering the behavioural component of attitude towards GMOs, reflected in the readiness to use GM organisms in treatment, the adolescents more rarely accepted such a possibility than readiness for buying and consuming GM food. In declarations of this type of behaviour, a considerable part of variance was delineated by emotional factors. Similar to other European inhabitants [25], the adolescents in the study were concerned about the risk of interfering with the human genetic code, and possibilities of releasing various pathogens, including those from GMOs, into the environment and human body. Individual behaviours are the consequence of these concerns, therefore, they result from an emotional-judgement attitude towards GMOs, and not knowledge concerning the possibilities of use of GM organisms for medicinal purposes.

Stepwise regression analysis showed a positive correlation between the respondents' readiness to undertake the production of GM plants or breed GM animals on their own farm, emotional factors and, to an even greater degree, correlation with the level of knowledge concerning the essence of genetic modifications. This seems relatively obvious considering the fact that any production requires primarily knowledge of the technology. Emotional engagement may favour the process of decision making concerning the type of production - whether to cultivate plants of breed animals; however, without professional knowledge satisfactory effects cannot be expected. The respondents were aware of this fact, which was reflected by a positive correlation between the declaration to produce GMOs, and the level of knowledge concerning the essence of genetic modifications.

\section{CONCLUSIONS}

The results of the presented study indicate that the declaration to use genetically modified products as food or medicines, to a greater degree, is conditioned more by an emotionaljudgement attitude than by the level of knowledge concerning genetic engineering.

In addition, willingness to produce genetically modified plants or animals on own farm proved to be significantly dependent on the level of knowledge of the problems pertaining to genetic modifications, followed by an emotional attitude towards the achievements of bio-technology.

Summing up, the results of the presented study indicate the need for the education of adolescents in the area of GMOs in order to shape the rational attitudes of young people towards the achievements of modern bio-technology.

\section{REFERENCES}

1. Daniel G. Gibson, Gwynedd A. Benders, Cynthia Andrews-Pfannkoch, Evgeniya A. Denisova i inni. Complete Chemical Synthesis, Assembly, and Cloning of a Mycoplasma genitalium Genome. „Science”. 2008; 319 (5867): 1215-1220.

2. Stanowisko Komitetu Biotechnologii przy Prezydium PAN w sprawie GMO (Attitude of Biotechnology Committee at Presidium of Polish Academy of Sciences in the matter of GMO) http://www.up.wroc. pl/p/ogloszenia/2013/stanowisko_komitetu_biotechnologii_pan.pdf (access: 2013.09.20)

3. Convention of Biological Diversity (with annexes). Concluded at Rio de Janeiro on 5 June 1992. United Nations Treaty. http://www.cbd.int/ doc/legal/cbd-en.pdf (access: 2013.09.20)

4. Abram WL, Crawley MJ. Report: Safety aspects of genetically modified foods of plant origin - FAO/WHO, Geneva, czerwiec 2000.

5. Ahmed FE. Detection of genetically modified organisms in foods. Trends Biotechnol. 2002; 20: 215-223.

6. Auer CA. Tracking genes from seed to supermarket: techniques and trends. Trend Plant Sci., 2003, 12: 591-597.

7. Korbin M. Uprawy GM, konwencjonalne i ekologiczne - problem koegzystencji. (GM crops, conventional and ecological - problem of coexistance) Biotechnologia, 2006; 3(74): 7-15.

8. Twardowska A. Żywność genetycznie zmodyfikowana i jej odbiór społeczny. (Genetically modified food and its social reception) Przem. Spoż., 2003; 10: 7-11.

9. http://www.farmio.com/prawne-regulacje-kwestii-gmo-w-polsce (access: 2013.09.20).

10. Cook AJ, Kerr GN, Moore K. Attitudes and intentions towards purchasing GM food. Journal of Economic Psychology, 23, 5, October, 2002; 557-572.

11. Crawley MJ, Brown SL, Hails RS i wsp. Transgenic crops in natural habitats. Nature, 2001; 409: 682-683.

12. Dąbrowski ZT, Twardowski T. GMO - Wprowadzenie. (GMO Introduction) Kosmos: Problemy Nauk Biologicznych 2007; 56; (3-4): 209-211.

13. Dąbrowski ZT. Doskonalenie metodyki oceny ryzyka uwolnienia GMO do środowiska i monitoringu: wybrane projekty badawcze UE. (Mastering methods of assessment of risk of releasing GMO into the natural environment and monitoring: selected research problems) Kosmos: Problemy Nauk Biologicznych 2007; 56, (3-4): 265-273.

14. Bonatowska K. Kontrowersje wokół GMO. (Controversy around GMO) Ekopartner. 2001; 11 (121): 38-39.

15. Mickiewicz A, Twardowski T, Figlerowicz M. GMO - zyski i straty. (GMO - profits and loss) Biotechnologia, 2006; 3(74): 145-152.

16. Tańska I. Problemy z GMO. (Problems with GMO) Bezpieczeństwo i Higiena Żywności, 2006; 37: 18-21.

17. Strelau J. Psychologia. GWP, 2006; Gdańsk.

18. Heritage J. The fate of transgens in human gut. Nature Biotechnology, 2004; 22: 170-172. 
19. http://www.isaaa.org/resources/publications/briefs/xx/pptslides/ Brief43slides.pdf (access: 2013.09.20).

20. James C. Global Status of Commercialized Biotech/GM Crops. ISAAA. www.isaaa.org

21. Jaworska A, Kapuścińska J. Opinie konsumentów, handlowców oraz odbiór społeczny w Polsce, krajach UE oraz na świecie na temat żywności modyfikowanej genetycznie. (Opinions by consumers, tradesmen and social receipt in Poland, in the EU countries and worldwide countries on genetically modified food) Wiedza Techniczna, 2010; 1: 63-64.

22. PBS DGA. www.pbsdga.pl (access: 2013.09.20)

23. Jurkiewicz A. Opinie młodzieży kończącej szkoły średnie na temat genetycznych modyfikacji organizmów i żywności modyfikowanej genetycznie. (niepublikowana rozprawa doktorska), (Opinions of adolescents completing secondary schools concerning genetic modification of organisms and genetically modified food - dissertation for doctor's degree) IMW, 2012, Biblioteka IMW.

24. Cynk K. Etyczne i społeczne konsekwencje osiągnięć nowoczesnej biotechnologii. (Ethical and social consequences of achievements of modern biotechnology) Wydawnictwo Uniwersytetu Rzeszowskiego, Rzeszów, 2013; 98-99.

25. Filiminow J, Berger S. Genetyka pod społeczną kontrolą, (Genetics under social control) Bezpieczeństwo i Higiena żywności, 2004; 3, 5: $36-37$. 